\title{
Comparison of the Efficacy of Three Natural Surfactants (Curosurf, Survanta, and Alveofact) in the Treatment of Respiratory Distress Syndrome Among Neonates: A Randomized Controlled Trial
}

\author{
Mirhadi Mussavi, ${ }^{1}$ Keyvan Mirnia, ${ }^{1}$ and Khairollah Asadollahi ${ }^{2,}$ \\ ${ }^{1}$ Department of Pediatrics, Faculty of Medicine, Pediatric Health Researches Center, University of Medical Sciences, Tabriz, IR Iran \\ ${ }^{2}$ Department of Social Medicine, Faculty of Medicine, Ilam University of Medical Sciences, Ilam, IR Iran \\ "Corresponding author: Khairollah Asadollahi, Department of Social Medicine, Faculty of Medicine, Ilam University of Medical Sciences, Ilam, IR Iran. Tel: +98-9143141230, Fax: \\ +98-4133272094, E-mail: masoud_1241@yahoo.co.uk
}

Received 2016 February 19; Revised 2016 May 15; Accepted 2016 June 15.

\begin{abstract}
Background: Although several different types of natural surfactants are available, including Alveofact, Curosurf, and Survanta, the preferred type and the magnitude of their effects are unknown.

objectives: This study was designed to compare the effects of these three surfactants on the gas exchange and clinical outcomes of neonates with respiratory distress syndrome (RDS).

Methods: This triple-blind randomized clinical trial studied all preterm neonates $\leq 37$ weeks with RDS who were admitted to the neonatal intensive care unit (NICU) of Taleghani hospital (Tabriz, Iran) between 2012 and 2013. The patients were divided into three groups, each of which received one of these surfactants. The incidences of ventilator dependency, patent ductus arteriosus (PDA), broncho-pulmonary dysplasia (BPD), retinopathy of prematurity (ROP), intraventricular hemorrhage (IVH), hospital-stay length, and continuous positive airway pressure (CPAP) failure, as well as blood gas levels, were recorded as endpoint measurements and compared.

Results: In total, 165 neonates of gestational age $\leq 37$ weeks with RDS were examined. Neonates were allocated to three different groups randomly, including a Survanta group $(n=49)$, a Curosurf group $(n=62)$, and an Alveofact group $(n=54)$. The mean gestational age of the neonates was $31.6 \pm$ 3.7 weeks, and their mean weight was 1,840 \pm 790 grams. The male/female ratio was 2:1 (67\% male, $33 \%$ female); 104 (63\%) neonates were $\leq 32$ weeks gestational age, and 61 (37\%) were $>32$ weeks. There were no significant differences for gender or demographic characteristics among the neonates in relation to the type of applied surfactant. According to the clinical parameters (BPD, IVH, ROP, hospital-stay length, and mechanical ventilation requirement), no significant differences were observed between the groups before and after surfactant administration, but the differences between the Survanta and Alveofact groups for the incidence rates of pneumothorax $(\mathrm{P}=0.03)$ and pulmonary hemorrhage $(\mathrm{P}=0.03)$ were statistically significant.

Conclusions: No significant differences were observed in most of the clinical variables between the three types of natural surfactant, but in neonates $\leq 32$ weeks, the incidence of pneumothorax was significantly higher in the Alveofact group; in neonates $>32$ weeks, the incidences of PDA, mean hospital-stay length, and mean mechanical ventilation time were also significantly higher in the same group. It thus appears that Curosurf and Survanta replacement therapies among premature neonates with RDS perform better than Alveofact replacement therapy.
\end{abstract}

Keywords: Neonates, Pulmonary Surfactant, Iran

\section{Background}

Surfactant replacement is a standard and widely used therapy for the treatment of respiratory distress syndrome (RDS) among premature neonates. The insufficient production of surfactants by preterm neonates leads to decreased lung compliance and increased alveolar surface tension, both of which increase the risk of alveolar collapse. There are two main types of surfactants: natural and synthetic $(1,2)$. Several randomized controlled trials and meta-analyses have reported the benefits of surfactant therapy in improving survival rates and the reduction of the incidence of pneumothorax. These studies have also confirmed that natural surfactants perform better than animal-protein-free types of synthetic surfactants.
Although several animal-derived surfactants are available, Alveofact, Curosurf, and Survanta are three that are administrated worldwide $(3,4)$. These animal-derived surfactants differ considerably in their composition (e.g., amounts of phospholipids, surfactant proteins B and C, and plasmalogens), viscosity, and volume that may influence their clinical effectiveness and clinical selection.

Different combinations of fat could explain some of the differences in surface viscosity. Beractant (Survanta, Abbott, Columbus, OH, USA) is a crushed bovine lungfat extract with the addition of palmitate colfosceril fatty acid and tripalmitin to standardize the composition. It is similar to other natural lung surfactants. Curosurf (poractant alfa, Chiesi Farmaceutici, Parma, Italy) is a lung 
surfactant derived from minced pork extract exposed to chloroform/methanol and liquid gel filtration chromatography; it contains the largest amount of phospholipids (PLs) with the smallest size distribution and also holds the largest amount of plasmalogens. Alveofact (BoehringerIngelheim Pharma, Ingelheim, Germany) is a fat that is derived from bovine lung lavage (5).

The patterns of PLs and minor superficial fat activity thus are important and must be considered when designing and preparing surfactants. Retrospective studies and large clinical trials have compared the clinical efficacy of animal-derived surfactants, although discussions of their effectiveness are ongoing $(6,7)$. The American Academy of Pediatrics declared in 2008 that it was "unclear whether significant differences in clinical outcomes between animal-derived surfactants exist" (8).

\section{Objectives}

Bearing the above factors in mind, we designed and performed this study to compare the effects of three types of surfactants derived from animals to determine any differences in the clinical outcomes and blood gases of preterm neonates with (or at risk for) RDS.

\section{Methods}

\subsection{Study Populations}

This triple-blind randomized clinical trial examined all neonates born between January 1, 2012, and December 31, 2013, of gestational age 37 weeks or younger with RDS admitted to the neonatal intensive care unit (NICU) of Taleghani hospital (Tabriz, Iran). The exclusion criteria included congenital anomalies, birth asphyxia (Apgar score of $<7$ at minute 5 , umbilical cord $\mathrm{pH}<7$, base excess (BE) $>-16)$, and gestational age over 38 weeks or postnatal age over 6 hours.

\subsection{Study Design}

The sample size was calculated with $95 \%$ confidence interval (CI), a power of $80 \%$, and standard deviation (SD) of 0.20 ; the total sample size of 108 premature infants was estimated to be least 36 neonates in each group. During the study period, however, and based on the convenience sampling method, 165 premature neonates aged 0 6 hours with signs of RDS were identified and assigned randomly to the three defined groups (Figure 1). The allocation was concealed in an opaque sealed envelope, according to which all patients had an equal chance of being assigned to one of the three groups; the patient care team, the data collectors, and the assessors were all blind to the three study groups. The primary expected outcomes were CPAP failure, ventilator dependence until 7 days after birth, blood $\mathrm{CO}_{2}$ and $\mathrm{SO}_{2}$ levels, and $\mathrm{BE}$. The secondary outcomes included IVH, PDA, pneumothorax, BPD, pulmonary hemorrhage, sepsis, and length of hospitalization. No one particular variable matched the patients' selection, except for the inclusion and exclusion criteria.

Three different groups were designed for the study: group 1 received Alveofact (100 $\mathrm{mg} / \mathrm{kg}$ ), group 2 received Poractant alfa (200 mg/kg), and group III received Beractant $(100 \mathrm{mg} / \mathrm{kg})$. Following the administration of the surfactant, the neonates were manually ventilated for $3-5$ minutes with a self-inflating bag; when satisfactory respiratory drive and oxygen saturation (peripheral capillary oxygen saturation $\left[\mathrm{SPO}_{2}\right] \geq 85 \%$ with fraction of inspired oxygen $\left[\mathrm{FiO}_{2}\right] \leq 30 \%$ ) were achieved, the neonatal endotracheal tube was removed; non-invasive respiratory support was administered until a CPAP level that was $0.5 \mathrm{~cm} \mathrm{H}_{2} \mathrm{O}$ less than the level of the pre-surfactant administration was reached. Before intubation, the neonates received a single intravenous bolus dose of fentanyl ( $1 \mathrm{mcg} / \mathrm{kg}$ ); for maintaining $\mathrm{SPO}_{2}$ percentage between $85 \%$ and $94 \%$, neonates were ventilated with bag/mask and supplemental oxygen if needed. After extubation to neutralize the effects of fentanyl in the neonates, $0.1 \mathrm{mg} / \mathrm{kg}$ Naloxone was administered intravenously. If a neonate had respiratory distress and required oxygen (gestational age $<30$ weeks and $\mathrm{FiO}_{2}$ $>30 \%$ requirement, or $>30$ weeks and $\mathrm{FiO}_{2}>40 \%$ requirement), the next dose of surfactant was administered after 6 - 12 hours and a second arterial blood gas (ABG) test was obtained 2 hours after surfactant administration.

According to the guidelines for the treatment of neonatal RDS in our ward, all preterm neonates that receive respiratory support with nasal CPAP (NCPAP) at admission are intubated after stabilization and treated by one of the three types of natural surfactant into the lungs until they show an appropriate respiratory score; after extubation, NCPAP is then continued (This is known as the "InSurE" procedure, for "intubation, surfactant, extubation" (9)).

The study design was approved by the ethics committee of the Tabriz University of Medical Sciences (institutional review board [IRB] number 8745), and informed consent was obtained from the parents of the neonates. The registration ID in the Iranian registry of clinical trials (IRCT) is IRCT201411028680N5.

\subsection{Variable Definitions and Diagnostic Criteria}

The diagnosis of RDS was based on classic signs (tachypnea, retraction, and grunting); radiological lung findings of reduced air content and a reticulonodular pattern; an air bronchogram; and a need for $\mathrm{FiO}_{2}>30 \%$ to maintain oxygen saturation above $90 \%$ (10). 
BPD was defined as oxygen dependency for 28 days; its severity was based on required $\mathrm{FiO} 2$ at 36 weeks of age after menstruation (11). Cranial ultrasound for the diagnosis of IVH was performed at 5-7 days of birth by a pediatric radiologist. Radiological evidence of pneumothorax was defined as an air leak that accumulated in the pleural space. Infection was confirmed if the clinical signs of sepsis with positive blood cultures existed. Diagnosis of PDA was based on the clinical signs and was confirmed by echocardiography, which was performed by a pediatric cardiologist.

\subsection{Statistical Analysis}

The statistical analysis was performed using SPSS software version 16; patients' characteristics were analyzed via tables of frequencies. The differences between the three independent groups were identified using ANOVA. If the frequency numbers of certain variables were less than five, the results were reported in the Fisher's exact test. In cases where the endpoint of a variable was continuous (or was binary) based on within- (before/after) or between-groups comparisons, paired or unpaired t-tests were used. The chisquare was used for comparison of categorical variables. The differences were considered to be significant at $\mathrm{P} \leq$ 0.05 .

\section{Results}

A total of 165 neonates with a mean gestational age of $31.6 \pm 3.7$ weeks and mean birth weight of $1,840 \pm 790$ grams were enrolled in this study. Curosurf was administrated to $62(37.6 \%)$ neonates, Alveofact to 54 (32.7\%), and Survanta to 49 (29.7\%). Table 1 demonstrates the demographic characteristics and several of the variables that were studied among the patients in the three groups.

Among the three groups, 58 neonates in the Curosurf group, 33 in the Survanta group, and 52 in the Alveofact group received at least one dose of surfactant. The median number of surfactant replacements was 1 (with a range of 1 - 6) in the studied patients, with $1(1-3)$ in the Curosurf group, 1(1-3) in the Survanta group and 1(1-6) in the Alveofact group. The mean time of ventilator support was $1.57 \pm$ 3.7 days in the Curosurf group, $1.08 \pm 1.9$ days in the Survanta group, and $1.89 \pm 2.9$ days in the Alveofact group; no significant differences were found between the three groups (Table 2 ).

The difference between Survanta and Alveofact for the incidence rate of pneumothorax $(\mathrm{P}=0.03)$ and pulmonary hemorrhage $(\mathrm{P}=0.03)$ was statistically significant; other comparisons did not reveal any significant difference (Table 3). InSurE failure and mechanical ventilation support requirement in neonates over 32 weeks was significantly lower in the Survanta group $(\mathrm{P}=0.019)$.
Comparing the effects of the three natural surfactants in newborns less than or more than 32 weeks revealed that in newborns $\leq 32$ weeks, the incidence of pneumothorax was significantly different between groups $(\mathrm{P}=0.026$; Table 4). In neonates over 32 weeks, however, there was a significant difference between groups for the incidence rate of PDA ( $\mathrm{P}=0.011)$; in addition, the length of the hospital stay was significantly different between groups $(\mathrm{P}=0.018$; Table 4).

The difference between Survanta and Alveofact for the incidence rate of pneumothorax $(\mathrm{P}=0.03)$ and pulmonary hemorrhage $(P=0.03)$ was statistically significant; other comparisons did not reveal any significant difference (Table 3). InSurE failure and mechanical ventilation support requirement in neonates over 32 weeks was significantly lower in the Survanta group $(\mathrm{P}=0.019)$.

Comparing the effects of the three natural surfactants in newborns less than or more than 32 weeks revealed that in newborns $\leq 32$ weeks, the incidence of pneumothorax was significantly different between groups $(\mathrm{P}=0.026$; Table 4). In neonates over 32 weeks, however, there was a significant difference between groups for the incidence rate of $\operatorname{PDA}(\mathrm{P}=0.011)$; in addition, the length of the hospital stay was significantly different between groups $(\mathrm{P}=0.018$; Table 4).

There was no significant difference for the other clinical parameters, such as retinopathy, pulmonary hemorrhage, NCPAP support, IVH, or BPD between the three groups (Table 4 ).

The comparison between the effects of the three types of surfactant on different blood-gas variables revealed significant differences, either in pre- or post-surfactant, for the mean $\mathrm{PCO} 2(\mathrm{P}=0.014, \mathrm{P}=0.003$ respectively), as well as for the mean $\mathrm{pH}$ in pre-surfactant therapy $(\mathrm{P}=0.014$; Table 5). Other comparisons did not show any significant differences.

\section{Discussion}

Exogenous surfactant replacement therapy is a standard procedure for respiratory distress syndrome among neonates. Surfactants are mainly obtained from lipid extract of pig or bovine lung and contain various amounts of lipophilic surface proteins. Our analysis of molecular species of phosphatidylcholine (PC) showed a significant difference between the different types of commercial surfactants (Survanta, Curosurf, and Alveofact) (5). Survanta has the highest proportion of total neutral lipids and the lowest proportion of polyunsaturated fatty acidcontaining phospholipids (PUFA-PLs). The highest concentration of plasmalogens and PUFA-PL was observed in Curosurf (3.8 \pm 0.1 vs. $26 \pm 1 \mathrm{~mol} \%$ ), in comparison with Alve- 


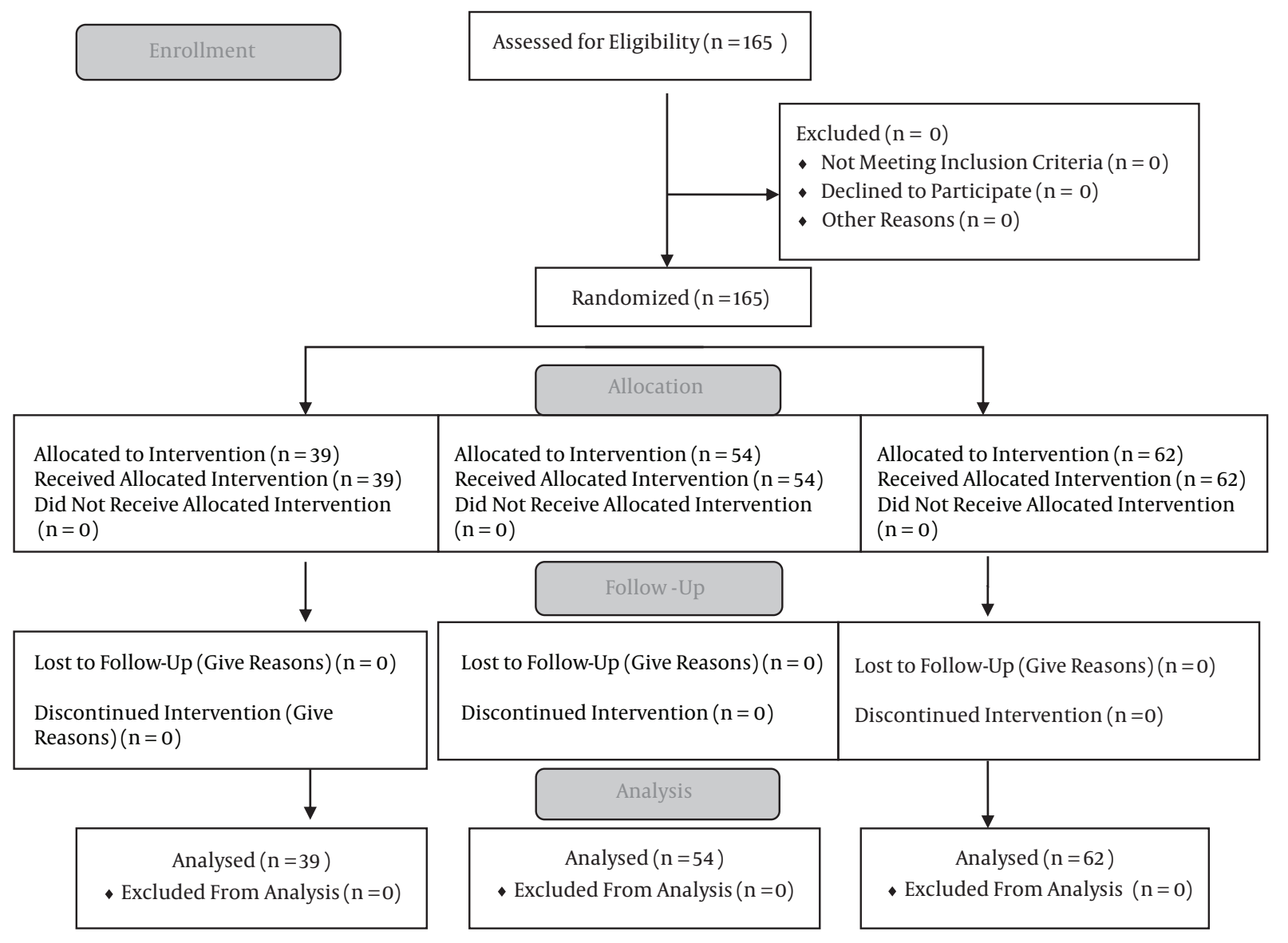

Figure 1. Flowchart of Patients' Enrollment in the Three Different Groups

ofact ( $0.9 \pm 0.3$ vs. \pm 11.1$)$ and Survanta (1.5 \pm 0.2 vs. 6 \pm 1 ). Different combinations of fat could explain some of the differences in the surface viscosities. The patterns of phospholipids (PLs) and superficial fat activities are important and must be considered when designing and preparing surfactants.

Surfactant therapy has significantly reduced mortality and disability in neonates; until now, natural surfactants have been shown to have a better prognosis than synthetic surfactants $(8,12)$. According to the results of a clinical meta-analysis, natural surfactants compared to synthetic surfactants substantially reduced the rates of pneumotho$\operatorname{rax}$ (risk ratio $[\mathrm{RR}]=0.63 ; 95 \% \mathrm{CI}, 0.53-0.75$ ) and mortality $(\mathrm{RR}=0.87 ; 95 \% \mathrm{CI}, 0.76-0.98)(13)$.

Although the effectiveness of surfactant therapy for the treatment of respiratory distress has been fully specified, it is not clear which kind of natural surfactant is preferable. Three natural surfactants (Survanta, Curosurf, and Alveofact) are available in Iran, but few studies have been performed on the effectiveness of these products for the treatment of neonatal respiratory distress. Differences in the structure and composition of these surfactants may influence their clinical effectiveness; we thus conducted this study to compare the effectiveness of the three natural surfactants.

In a prospective study by Baroutis et al. (14), three natural surfactants (Alveofact, Curosurf, and Survanta) were compared among neonates with RDS; the authors found several significant differences in their clinical outcomes. Curosurf compared to Survanta showed significantly fewer days for mechanical ventilation $(P=0: 043)$ as well as fewer days on supplemental oxygen therapy $(\mathrm{P}=$ 0: 04); they observed a reduced length of stay in the hospital (LOS) among those receiving Curosurf compared to 
Table 2. Comparison Between the Effects of the Three Types of Surfactants on Different Variables Among Neonates Receiving Surfactant After Intervention

\begin{tabular}{|c|c|c|c|c|}
\hline \multirow[t]{2}{*}{ Variable } & \multicolumn{4}{|c|}{ Type of Surfactant } \\
\hline & Survanta & Alveofact & Curosurf & PValue $^{a}$ \\
\hline Duration of hospital stay (mean \pm SD) (days) & $15.37 \pm 14.2$ & $15.47 \pm 12.5$ & $14.35 \pm 12.6$ & 0.892 \\
\hline Birth weight (mean \pm SD) (gr) & $1829 \pm 782$ & $1815 \pm 729$ & $1873 \pm 859$ & 0.926 \\
\hline Gestational age (mean $\pm S \mathrm{SD})$ (weeks) & $31.56 \pm 3.8$ & $31.46 \pm 3.6$ & $31.70 \pm 3.8$ & 0.949 \\
\hline Ventilation time (mean \pm SD) (days) & $1.08 \pm 1.9$ & $1.89 \pm 2.9$ & $1.57 \pm 3.7$ & 0.765 \\
\hline Number of surfactant injections (mean \pm SD) & $1.08 \pm 0.33$ & $1.55 \pm 1.12$ & $1.06 \pm 0.3$ & 0.043 \\
\hline Pneumothorax & & & & 0.070 \\
\hline Yes & $2(16.7)$ & $7(58.3)$ & $3(25)$ & \\
\hline No & $60(39.2)$ & $42(27.5)$ & $51(33.3)$ & \\
\hline Patent ductus arteriosus & & & & 0.375 \\
\hline Yes & $8(29.6)$ & $11(40.8)$ & $8(29.6)$ & \\
\hline No & $54(39.1)$ & $38(27.5)$ & $46(33.4)$ & \\
\hline BPD & & & & 0.782 \\
\hline Yes & $2(50)$ & $1(25)$ & $1(25)$ & \\
\hline No & $60(37.3)$ & $48(29.8)$ & $53(32.9)$ & \\
\hline Intracranial hemorrhage & & & & 0.841 \\
\hline Yes & $7(41.2)$ & $4(23.5)$ & $6(35.3)$ & \\
\hline No & $55(37.2)$ & $45(30.4)$ & $48(32.4)$ & \\
\hline NCPAP support & & & & 0.542 \\
\hline Yes & $51(35.9)$ & $43(30.3)$ & $48(33.8)$ & \\
\hline No & $11(47.8)$ & $6(26.1)$ & $6(26.1)$ & \\
\hline Pulmonary hemorrhage & & & & 0.055 \\
\hline Yes & $3(18.6)$ & $9(56.4)$ & $4(25)$ & \\
\hline No & $59(39.6)$ & $40(26.8)$ & $50(33.6)$ & \\
\hline Retinopathy & & & & 0.298 \\
\hline Yes & $1(33.3)$ & $2(66.7)$ & $0(0)$ & \\
\hline No & $61(37.7)$ & $47(29)$ & $54(33.3)$ & \\
\hline
\end{tabular}

${ }^{\mathrm{a}}$ ANOVA and crosstabs tests.

Survanta ( $\mathrm{P}=0$ : 027) and Alveofact $(\mathrm{P}=0: 04)$. In our study, InSurE failure and mechanical ventilation support requirement in neonates over 32 weeks was significantly lower in the Survanta group. We found a significant difference for hospital-stay length in the Alveofact group $(\mathrm{P}=0.018$; Table 4).

Ramanathan et al. (15) conducted a prospective comparison of Curosurf and Survanta and observed a significant reduction of the $\mathrm{FiO}_{2}$ requirement in the Curosurf group; they found that a higher initial dose of Curosurf (200 mg) was significantly associated with a lower mortality rate $(\mathrm{P}=0: 05)$. Proquitte et al. (16) conducted a retrospective observational study to compare the effects of Alve- ofact and Curosurf on gas exchange and outcome among premature neonates. According to their report, there were no statistically significant differences between neonates treated by Alveofact and Curosurf in terms of mean gestational age (28.4 vs. 29.4 weeks), birth weight (1, $210 \mathrm{~g}$ vs.1, $258 \mathrm{~g}$ ), or time of first surfactant application (60 vs. 90 min postnatal). They also found no significant differences between these groups for $\mathrm{FiO}_{2}$ and blood gases or in incidence rates of BPD ( $41.7 \%$ vs. $42.8 \%)$, IVH III/IV (18.3\% vs. $14.3 \%)$, pneumothorax (9.8\% vs. $4.8 \%$ ), PDA (23.2\% vs. $21.9 \%$ ), PVL (7.3\% vs. $9.5 \%$ ), or death rate (17\% vs. $17.1 \%$ ) at day 28. They concluded that independent of gestational age, there was no significant difference between the clinical ef- 


\begin{tabular}{|c|c|c|c|c|c|c|c|c|c|}
\hline \multirow[t]{2}{*}{ Variable } & \multicolumn{9}{|c|}{ Type of Surfactant } \\
\hline & Survanta No. (\%) & Alveofact №. (\%) & PValue $^{\mathbf{a}}$ & Curosurf No. (\%) & Alveofact No. (\%) & Curosurf No. (\%) & PValue $^{\mathbf{a}}$ & Survanta No. (\%) & PValue $^{\mathbf{a}}$ \\
\hline Pneumothorax & & & 0.03 & & & & 0.1 & & 0.5 \\
\hline Yes & $2(22.2)$ & $7(77.8)$ & & $3(30)$ & $7(70)$ & $3(60)$ & & $2(40)$ & \\
\hline No & $60(58.8)$ & $42(41.2)$ & & $51(54.8)$ & $42(45.2)$ & $51(46)$ & & $60(54)$ & \\
\hline Patent ductus arteriosus & & & 0.2 & & & & 0.3 & & 0.8 \\
\hline Yes & $8(42.1)$ & $11(57.9)$ & & $8(42.1)$ & $11(57.9)$ & $8(50)$ & & $8(50)$ & \\
\hline No & $54(58.7)$ & $38(41.3)$ & & $46(54.8)$ & $38(45.2)$ & $46(46)$ & & $54(54)$ & \\
\hline BPD & & & 0.6 & & & & 0.9 & & 0.6 \\
\hline Yes & $2(66.7)$ & $1(33.3)$ & & $1(50)$ & $1(50)$ & $1(33.3)$ & & $2(66.7)$ & \\
\hline No & $60(55.6)$ & $48(44.4)$ & & $53(52.5)$ & $48(47.5)$ & $53(46.9)$ & & $60(53.1)$ & \\
\hline Intracranial hemorrhage & & & 0.8 & & & & 0.6 & & 0.9 \\
\hline Yes & $7(63.6)$ & $4(36.4)$ & & $6(60)$ & $4(40)$ & $6(46.2)$ & & $7(53.8)$ & \\
\hline No & $55(55)$ & $45(45)$ & & $48(51.6)$ & $45(48.4)$ & $48(46.6)$ & & $55(53.4)$ & \\
\hline NCPAP support & & & 0.1 & & & & 0.3 & & 0.8 \\
\hline Yes & $51(54.3)$ & $43(45.7)$ & & $48(52.8)$ & $43(47.2)$ & $48(48.5)$ & & $51(51.5)$ & \\
\hline No & $11(64.7)$ & $6(35.3)$ & & $6(50)$ & $6(50)$ & $6(35.3)$ & & $11(64.7)$ & \\
\hline Pulmonary hemorrhage & & & 0.03 & & & & 0.09 & & 0.5 \\
\hline Yes & $3(25)$ & $9(75)$ & & $4(30.8)$ & $9(69.2)$ & $4(57.1)$ & & $3(42.9)$ & \\
\hline No & $59(59.6)$ & $40(40.4)$ & & $50(55.6)$ & $40(44.4)$ & $50(45.9)$ & & $59(54.1)$ & \\
\hline Retinopathy & & & 0.6 & & & & 0.2 & & 0.4 \\
\hline Yes & $1(33.3)$ & $2(66.7)$ & & 0 & $2(100)$ & $0(0)$ & & $1(100)$ & \\
\hline No & $61(56.5)$ & $47(43.5)$ & & $54(53.5)$ & $47(46.5)$ & $54(47)$ & & $61(53)$ & \\
\hline
\end{tabular}

${ }^{\mathrm{a}}$ Descriptive test (crosstabs).

ficacy of Alveofact and Curosurf. Our study showed that there were no significant differences in the post-surfactant blood-gas parameters, except for $\mathrm{PCO} 2$ in either pre- or post-surfactant therapy $(\mathrm{P}=0.014$ and $\mathrm{P}=0.003$, respectively). Proquitte et al.'s findings were consistent with the results of our study, which revealed no significant differences in the clinical parameters retinopathy, PDA, pulmonary hemorrhage, IVH, or BPD in the three groups.

Our study showed that the incidence of PDA in neonates above 32 weeks was significantly greater in the Alveofact group ( $\mathrm{P}=0.011$ ); we also found that hospital-stay length for those in the Survanta group was shorter than that in the other two groups $(\mathrm{P}=0.018)$.

Malloy et al. (17) compared the effects of Survanta and Curosurf among neonates with RDS. The primary outcome of their measurement was the $\mathrm{FiO}_{2}$ requirement in the first 48 hours after surfactant therapy. They concluded that neonates with RDS treated with Poractant had a lower $\mathrm{FiO}_{2}$ requirement during the first 48 hours compared to those who received Beractant. Neonates who received Poractant also had fewer PDA than neonates who received Beractant. The difference in $\mathrm{FiO}_{2}$ between groups was not associated with a difference in age of first extubation, total intubation time, or incidence of BPD.

Yalaz and colleagues (18) compared the effectiveness and side-effects (pneumothorax, sepsis, intraventricular hemorrhage, and BPD) of two natural surfactants (Alveofact and Survanta) and reported no statistical differences between the two groups. They concluded that despite the dissimilarity in the compositions of these surfactants, they did not reveal significant differences in terms of final effects or side-effects. In our study, our comparison of the effects of these three natural surfactants between newborns under and above 32 weeks revealed that the incidences of pneumothorax $(\mathrm{P}=0.026)$ and $\mathrm{PDA}(\mathrm{P}=0.011)$ were significantly different among newborns under and over 32 weeks, respectively.

Hammoud et al. (19) compared the efficacy of two natural surfactants (SF-RI1 [Alveofact] and Beractant [Survanta]) on incidences of chronic lung diseases (CLDs) and other associated complications of RDS in preterm neonates. Those with RDS requiring artificial ventilation were randomly selected to receive an initial dose of either Alveofact or Survanta. The two treatment groups were tested for variations in gas exchange, ventilator settings, and neonatal complications (such as CLD and mortality). The authors reported improved oxygenation and reduced ventilator requirements in the Survanta group compared to the Alveofact group, which in turn was associated with a trend toward a lower incidence of serious pulmonary complica- 
Table 4. The effects Of Three Types of Surfactant on Different Variables among Neonates Receiving Surfactant according to Their Gestational Age After Intervention

\begin{tabular}{|c|c|c|c|c|c|c|c|c|}
\hline \multirow[t]{2}{*}{ Variable } & \multicolumn{4}{|c|}{ Type of Surfactant $\leq 32$ Weeks } & \multicolumn{4}{|c|}{ Type of Surfactant $>32$ Weeks } \\
\hline & Survanta & Alveofact & Curosurf & PValue* & Survanta & Alveofact & Curosurf & PValue $^{\mathrm{a}}$ \\
\hline Duration of hospital stay (mean \pm SD) (days) & $19.14 \pm 15.9$ & $17.43 \pm 14.7$ & $18.12 \pm 14.8$ & 0.892 & $8.0 \pm 4.84$ & $12.37 \pm 6.97$ & $8.43 \pm 3.12$ & 0.018 \\
\hline Birth weight (mean \pm SD) (gr) & $1411 \pm 42$ & $1385 \pm 33$ & $1319 \pm 37$ & 0.571 & $2645 \pm 68$ & $2496 \pm 67$ & $2745 \pm 66$ & 0.504 \\
\hline Gestational age (mean $\pm \mathrm{SD}$ ) (weeks) & $29.4 \pm 2.2$ & $29.1 \pm 1.9$ & $29.2 \pm 2.1$ & 0.845 & $35.9 \pm 2.3$ & $34.2 \pm 1.0$ & $35.7 \pm 1.7$ & 0.567 \\
\hline Ventilation time (mean \pm SD) (days) & $1.37 \pm 2.1$ & $1.87 \pm 3.3$ & $1.82 \pm 4.2$ & 0.765 & $0.52 \pm 1.3$ & $1.95 \pm 2.4$ & $1.19 \pm 2.7$ & 0.019 \\
\hline Pneumothorax & & & & & & & & 0.218 \\
\hline Yes & $2(28.6)$ & $5(71.4)$ & 0 & 0.026 & 0 & $2(40)$ & $3(60)$ & \\
\hline No & $39(40.2)$ & $25(25.8)$ & $33(34)$ & & $21(37.5)$ & $17(30.4)$ & $18(32.1)$ & \\
\hline Patent ductus arteriosus & & & & & & & & 0.011 \\
\hline Yes & $8(42.1)$ & $5(26.3)$ & $6(31.6)$ & 0.954 & 0 & $6(75)$ & $2(25)$ & \\
\hline No & $33(38.8)$ & $25(29.4)$ & $27(31.8)$ & & $21(39.6)$ & $13(24.5)$ & $19(35.9)$ & \\
\hline BPD & & & & & & & & - \\
\hline Yes & $2(50)$ & $1(25)$ & $1(25)$ & 0.905 & 0 & 0 & 0 & - \\
\hline No & $39(39)$ & $29(29)$ & $32(32)$ & & $21(34.4)$ & $19(31.2)$ & $21(34.4)$ & \\
\hline Intracranial hemorrhage & & & & & & & & - \\
\hline Yes & $7(41.2)$ & $4(23.5)$ & $6(35.3)$ & 0.862 & 0 & 0 & 0 & - \\
\hline No & $34(39.1)$ & $26(29.9)$ & $27(31)$ & & $21(34.4)$ & $19(31.2)$ & $21(34.4)$ & \\
\hline NCPAP support & & & & 0.817 & & & & 0.607 \\
\hline Yes & $34(38.2)$ & $26(29.2)$ & $29(32.6)$ & & $17(40.5)$ & $9(21.4)$ & $16(38.1)$ & \\
\hline No & $7(46.6)$ & $4(26.7)$ & $4(26.7)$ & & $4(50)$ & $2(25)$ & $2(25)$ & \\
\hline Pulmonary hemorrhage & & & & 0.077 & 0.077 & & 0 & 0.325 \\
\hline Yes & $3(20)$ & $8(53.3)$ & $4(26.7)$ & & 0 & $001(100)$ & 0 & \\
\hline No & $38(42.7)$ & $22(24.7)$ & $29(32.6)$ & & $21(34.4)$ & $19(31.2)$ & $21(34.4)$ & \\
\hline Retinopathy & & & & 0.600 & & & & 0.325 \\
\hline Yes & $1(50)$ & $1(50)$ & 0 & & & $1(100)$ & 0 & \\
\hline No & $40(39.2)$ & $29(28.4)$ & $33(32.4)$ & & $21(34.4)$ & $19(31.2)$ & $21(34.4)$ & \\
\hline
\end{tabular}

${ }^{\mathrm{a}}$ ANOVA and crosstabs tests.

tions. In our study, comparison between the effects of Survanta and Alveofact on different variables revealed a significantly increased rate of pneumothorax and pulmonary hemorrhage in the Alveofact group than in the Survanta group, which in some ways was in accordance with Hammoud et al.'s study.

Manizheh and Sanaz compared the efficacy of two natural surfactants (Curosurf and Alveofact) in the treatment of RDS in preterm neonates and found that the mean number of surfactant replacement therapies was significantly higher in the Alveofact group than in the Curosurf group (1.79 \pm 0.92 vs. $1.22 \pm 0.48, \mathrm{P}<0.001)$. Nine neonates, all of whom were treated with Alveofact, needed to remain on ventilator support for 7 days. The authors also reported a significantly higher mean duration of oxygen supplementation in the Alveofact group versus the Curosurf group, with similar rates of complications among patients in the two groups (11). The results of our study have shown that the mean of ventilator support time was $1.57 \pm 3.7$ in the Curosurf group, $1.08 \pm 1.9$ in the Survanta group, and 1.89 \pm 2.9 in the Alveofact group; we found no significant differences between groups. The mean number of surfactant replacement therapies was significantly higher in the Alveofact group than in the Curosurf or Alveofact groups.

\subsection{Conclusion}

Based on several clinical variables, no significant differences were observed in most of the variables between 
Table 5. The Effects of Three Types of Surfactant on Different Variables Among Neonates according to Pre- or Post-Surfactant Application After Intervention

\begin{tabular}{|c|c|c|c|c|c|c|c|c|}
\hline \multirow[t]{2}{*}{ Variable } & \multicolumn{4}{|c|}{ Type of Surfactant (Pre-Surfactant) } & \multicolumn{4}{|c|}{ Type of Surfactant (Post-Surfactant) } \\
\hline & Survanta & Alveofact & Curosurf & PValue $^{\mathrm{a}}$ & Survanta & Alveofact & Curosurf & P Value $^{\mathbf{a}}$ \\
\hline $\mathrm{pH}($ mean $\pm \mathrm{SD})$ & $7.38 \pm 0.1$ & $7.27 \pm 0.25$ & $7.26 \pm 0.28$ & 0.014 & $7.37 \pm 0.39$ & $7.34 \pm 0.22$ & $7.28 \pm 0.23$ & 0.219 \\
\hline $\mathrm{PCO}_{2}{ }^{\mathbf{b}}($ mean $\pm \mathrm{SD})$ & $37.7 \pm 11.9$ & $42.6 \pm 12.4$ & $44.2 \pm 14.7$ & 0.014 & $33.7 \pm 11$ & $39.2 \pm 12.9$ & $43.7 \pm 13.8$ & 0.003 \\
\hline $\mathrm{PO}_{2}^{\mathrm{C}}($ mean $\pm S D)$ & $65.6 \pm 50.9$ & $63.3 \pm 25.8$ & $62.5 \pm 33.4$ & 0.197 & $65.5 \pm 35.6$ & $51.4 \pm 20.1$ & $63.7 \pm 49.3$ & 0.428 \\
\hline
\end{tabular}

${ }^{\mathrm{a}} \mathrm{ANOVA.}$

${ }^{\mathrm{b}} \mathrm{PCO}_{2}$, partial pressure of carbon dioxide in the blood.

${ }^{\mathrm{c}} \mathrm{PO}_{2}$, partial pressure of oxygen in the blood.

the three types of natural surfactant, but in neonates $\leq 32$ weeks, the incidence of pneumothorax was significantly higher in the Alveofact group; in neonates < 32 weeks, the incidences of PDA, mean hospital-stay length, and mean ventilation times were also significantly higher in the same group. It thus appears that replacement therapy with the natural surfactants Curosurf and Survanta in premature neonates with respiratory distress exhibit better performance than replacement therapy with Alveofact. Surfactant readministration for maintaining lung recruitment was higher in the Alveofact group compared to the other surfactants.

\section{Acknowledgments}

This study was supported by the pediatric health research center at the Tabriz University of Medical Sciences. We thank the NICU nurses involved in the care of the neonates studied in this report.

\section{Footnote}

Authors' Contribution: Mirhadi Mussavi designed the initial concept, prepared the manuscript, and helped with the first draft of the manuscript. Khairollah Asadollahi analyzed and interpreted the data and participated in manuscript preparation and critical revision. Keyvan Mirnia participated in manuscript preparation and data collection. All authors read and approved of the final version of article.

\section{References}

1. Singh N, Hawley KL, Viswanathan K. Efficacy of porcine versus bovine surfactants for preterm newborns with respiratory distress syndrome: systematic review and meta-analysis. Pediatrics. 2011;128(6):1588-95. doi: 10.1542/peds.2011-1395. [PubMed: 22123870].

2. Soll R, Blanco F. Natural surfactant extract versus synthetic surfactant for neonatal respiratory distress syndrome. Cochrane Database Syst Rev. 2001;2:144.
3. Soll R, Ozek E. Multiple versus single doses of exogenous surfactant for the prevention or treatment of neonatal respiratory distress syndrome. Cochrane Database Syst Rev. 2009(1):141. doi: 10.1002/14651858.CD000141.pub2. [PubMed: 19160177].

4. Ramanathan R. Animal-derived surfactants: where are we? The evidence from randomized, controlled clinical trials.JPerinatol. 2009;29 Suppl 2:38-43. doi: 10.1038/jp.2009.31. [PubMed: 19399008].

5. Rudiger M, Tolle A, Meier W, Rustow B. Naturally derived commercial surfactants differ in composition of surfactant lipids and in surface viscosity. Am J Physiol Lung Cell Mol Physiol. 2005;288(2):379-83. doi: 10.1152/ajplung.00176.2004. [PubMed: 15501950].

6. Ma CC, Ma S. The role of surfactant in respiratory distress syndrome. Open Respir Med J. 2012;6:44-53. doi: 10.2174/1874306401206010044. [PubMed: 22859930].

7. Halliday HL. Surfactants: past, present and future. JPerinatol. 2008;28 Suppl 1:47-56. doi: 10.1038/jp.2008.50. [PubMed: 18446178].

8. Engle WA, American Academy of Pediatrics Committee on F. Surfactant-replacement therapy for respiratory distress in the preterm and term neonate. Pediatrics. 2008;121(2):419-32. doi: 10.1542/peds.2007-3283. [PubMed: 18245434].

9. Verder H, Agertoft L, Albertsen P, Christensen NC, Curstedt T, Ebbesen $\mathrm{F}$, et al. [Surfactant treatment of newborn infants with respiratory distress syndrome primarily treated with nasal continuous positive air pressure. A pilot study]. Ugeskr Laeger. 1992;154(31):2136-9. [PubMed: 1509593].

10. Sweet DG, Carnielli V, Greisen G, Hallman M, Ozek E, Plavka R, et al European consensus guidelines on the management of neonatal respiratory distress syndrome in preterm infants-2013 update. Neonatology. 2013;103(4):353-68. doi: 10.1159/000349928. [PubMed: 23736015].

11. Manizheh MG, Sanaz Y. Comparing the effect of two natural surfactant, Curosurf and Alveofact in treatment of respiratory distress syndrome in preterm infants. Int J Women's Health Repr Sci. 2014;2:245-8.

12. Rojas MA, Lozano JM, Rojas MX, Laughon M, Bose CL, Rondon MA, et al. Very early surfactant without mandatory ventilation in premature infants treated with early continuous positive airway pressure: a randomized, controlled trial. Pediatrics. 2009;123(1):137-42. doi: 10.1542/peds.2007-3501. [PubMed: 19117872].

13. Corff KE, Greubel S, McCann DG, Williams R, Varner DL. Practical Considerations in the Selection and Use of Pulmonary Surfactant Therapy for Neonatal Respiratory Distress Syndrome in the Intensive Care Setting. J Pediatr Pharmacol Ther. 2006;11:161-8.

14. Baroutis G, Kaleyias J, Liarou T, Papathoma E, Hatzistamatiou Z, Costalos C. Comparison of three treatment regimens of natural surfactant preparations in neonatal respiratory distress syndrome. Eur J Pediatr. 2003;162(7-8):476-80. doi: 10.1007/s00431-002-1144-0. [PubMed: 12709796]. 
15. Ramanathan R, Rasmussen MR, Gerstmann DR, Finer N, Sekar K, North American Study G. A randomized, multicenter masked comparison trial of poractant alfa (Curosurf) versus beractant (Survanta) in the treatment of respiratory distress syndrome in preterm infants. Am JPerinatol. 2004;21(3):109-19. doi:10.1055/s-2004-823779. [PubMed: 15085492].

16. Proquitte H, Dushe T, Hammer H, Rudiger M, Schmalisch G, Wauer RR. Observational study to compare the clinical efficacy of the natural surfactants Alveofact and Curosurf in the treatment of respiratory distress syndrome in premature infants. Respir Med. 2007;101(1):16976. doi:10.1016/j.rmed.2006.03.033. [PubMed:16698258].

17. Malloy CA, Nicoski P, Muraskas JK. A randomized trial comparing beractant and poractant treatment in neonatal respira- tory distress syndrome. Acta Paediatr. 2005;94(6):779-84. doi: 10.1080/08035250510028740. [PubMed: 16188788].

18. Yalaz M, Arslanoglu S, Akisu M, Atik T, Ergun O, Kultursay N. A comparison of efficacy between two natural exogenous surfactant preparations in premature infants with respiratory distress syndrome. Klin Padiatr. 2004;216(4):230-5. doi: 10.1055/s-2004-44899. [PubMed: 15284947].

19. Hammoud M, Al-Kazmi N, Alshemmiri M, Thalib L, Ranjani VT, Devarajan LV, et al. Randomized clinical trial comparing two natural surfactant preparations to treat respiratory distress syndrome. J Matern Fetal Neonatal Med. 2004;15(3):167-75. doi: 10.1080/14767050410001668266. [PubMed: 15280142]. 
Table 1. General Characteristics and Frequency of Different Variables Among Participants Before Intervention

\begin{tabular}{|c|c|c|c|c|c|}
\hline \multirow[t]{2}{*}{ Variable } & \multicolumn{4}{|c|}{ Type of Surfactant } & \multirow[t]{2}{*}{ Total (\%) } \\
\hline & Curosurf No. (\%) & Alveofact No. (\%) & Survanta No. (\%) & PValue $^{\mathbf{a}}$ & \\
\hline Sex & & & & 0.07 & \\
\hline Male & $37(33.6)$ & $39(35.5)$ & $34(30.9)$ & & $110(67)$ \\
\hline Female & $25(45.5)$ & $10(18.2)$ & $20(36.3)$ & & $55(33)$ \\
\hline $\begin{array}{l}\text { Gestational age } \\
\text { (weeks) }\end{array}$ & & & & 0.8 & \\
\hline$\leq 32$ & $41(39.4)$ & $30(28.9)$ & $33(31.7)$ & & $104(63)$ \\
\hline$>32$ & $21(34.4)$ & $19(31.2)$ & $21(34.4)$ & & $61(37)$ \\
\hline Birth weight (gr) & & & & 0.3 & \\
\hline$<1,500$ & $28(45.2)$ & $24(38.7)$ & $10(16.1)$ & & $62(42)$ \\
\hline $\begin{array}{l}1,500- \\
2,500\end{array}$ & $18(36.7)$ & $22(44.9)$ & $9(18.4)$ & & $49(37)$ \\
\hline$>2,500$ & $24(44.4)$ & $15(27.8)$ & $15(27.8)$ & & $54(21)$ \\
\hline Sepsis & & & & 0.5 & \\
\hline Yes & $13(30.2)$ & $15(34.9)$ & $15(34.9)$ & & $43(26)$ \\
\hline No & $49(40.2)$ & $34(27.9)$ & $39(31.9)$ & & $122(74)$ \\
\hline Pneumothorax & & & & 0.07 & \\
\hline Yes & $2(16.7)$ & $7(58.3)$ & $3(25)$ & & $12(7)$ \\
\hline No & $60(39.2)$ & $42(27.5)$ & $51(33.3)$ & & $153(93)$ \\
\hline Mode of delivery & & & & 0.5 & \\
\hline Vaginal & $16(31.4)$ & $16(31.4)$ & $19(37.2)$ & & $51(31)$ \\
\hline$c / S$ & $46(40.4)$ & $33(28.9)$ & $35(30.7)$ & & $114(69)$ \\
\hline $\begin{array}{l}\text { Patent ductus } \\
\text { arteriosus }\end{array}$ & & & & 0.4 & \\
\hline Yes & $8(29.6)$ & $11(40.7)$ & $8(29.7)$ & & $27(16)$ \\
\hline No & $54(39.1)$ & $38(27.5)$ & $46(33.4)$ & & $138(84)$ \\
\hline $\begin{array}{l}\text { Ventilator } \\
\text { therapy }\end{array}$ & & & & 0.1 & \\
\hline Yes & $19(29.2)$ & $24(36.9)$ & $22(33.9)$ & . & $65(39)$ \\
\hline No & $43(43)$ & $25(25)$ & $32(32)$ & & $100(61)$ \\
\hline Retinopathy & & & & 0.3 & \\
\hline Yes & $1(33.3)$ & $2(66.7)$ & 0 & & $3(2)$ \\
\hline No & $61(37.7)$ & $47(29)$ & $54(33.3)$ & & $162(98)$ \\
\hline $\begin{array}{l}\text { Bronchopulmonary } \\
\text { dysplasia }\end{array}$ & & & & 0.9 & \\
\hline Yes & $2(50)$ & $1(25)$ & $1(25)$ & & $4(2)$ \\
\hline No & $60(37.3)$ & $48(29.8)$ & $53(32.9)$ & & $161(98)$ \\
\hline $\begin{array}{l}\text { Intracranial } \\
\text { hemorrhage }\end{array}$ & & & & 0.8 & \\
\hline Yes & $7(41.2)$ & $4(23.5)$ & $6(35.3)$ & & $17(10)$ \\
\hline No & $55(37.2)$ & $45(30.4)$ & $48(32.4)$ & & $148(90)$ \\
\hline NCPAP support & & & & 0.6 & \\
\hline 0 & $42(42)$ & $25(25)$ & $33(33)$ & & $100(80)$ \\
\hline $\begin{array}{c}\text { Pulmonary } \\
\text { hemorrhage }\end{array}$ & & & & 0.06 & \\
\hline Yes & $3(18.8)$ & $9(56.3)$ & $4(24.9)$ & & $16(10)$ \\
\hline No & $59(39.6)$ & $40(26.9)$ & $50(33.5)$ & & $149(90)$ \\
\hline $\begin{array}{l}\text { Preterm rupture } \\
\text { of membrane }\end{array}$ & & & & 0.1 & \\
\hline Yes & $3(25)$ & $2(16.7)$ & $7(58.3)$ & & $12(7)$ \\
\hline No & $59(38.6)$ & $47(30.7)$ & $47(30.7)$ & & $153(93)$ \\
\hline Preeclampsia & & & & 0.3 & \\
\hline Yes & $4(21.1)$ & $7(36.8)$ & $8(42.1)$ & & $19(11)$ \\
\hline No & $58(39.7)$ & $42(28.8)$ & $46(31.5)$ & & $146(89)$ \\
\hline IDM & & & & 0.2 & \\
\hline Yes & 0 & $1(25)$ & $3(75)$ & & $4(2)$ \\
\hline No & $62(38.5)$ & $48(29.8)$ & $51(31.7)$ & & $161(98)$ \\
\hline Death & & & & 0.5 & \\
\hline Yes & $11(30.6)$ & $13(36.1)$ & $12(33.3)$ & & $36(22)$ \\
\hline No & $51(39.5)$ & $36(27.9)$ & $42(32.6)$ & & $129(78)$ \\
\hline
\end{tabular}

${ }^{\mathrm{a}}$ Descriptive test (crosstabs) 